\title{
Nitric Oxide Fumigation Delays Mango Fruit Ripening
}

\author{
Zaharah, S.S. and Zora Singh
}

Curtin Horticulture Research Laboratory, Department of Environment and Agriculture, School of Science, Faculty of Science and Engineering, Curtin University, GPO Box U1987, Perth 6845, WA, Australia.

Email: szaharah@putra.upm.edu.my / z.singh@curtin.edu.au

Keywords: Mangifera indica, ethylene, respiration, ripening, individual sugars, quality

\begin{abstract}
Hard mature green 'Kensington Pride' mango fruit were fumigated with 0,5 , 10, 20 and $40 \mu \mathrm{L} . \mathrm{L}^{-1}$ NO gas for $2 \mathrm{~h}$ and allowed to ripen at ambient temperature $\left(21 \pm 1^{\circ} \mathrm{C}\right)$ to evaluate its effects on fruit ripening. NO-fumigation treatments significantly $(P \leq 0.05)$ suppressed ethylene production and respiration rates during fruit ripening. NO treatments $\left(20\right.$ and $\left.40 \mu \mathrm{L} . \mathrm{L}^{-1}\right)$ retarded fruit softening (hand firmness) and delayed fruit ripening by 2-days as compared to all other treatments. NO-fumigated $\left(40 \mu \mathrm{L} . \mathrm{L}^{-1}\right)$ ripe fruit exhibited significantly higher pulp cohesiveness, springiness and chewiness as compared to all other treatments. NO fumigation retarded fruit color development (visual colour, $L^{*}, a^{*}, b^{*}, C^{*}$ ) and delayed the reduction of $h^{o}$ during fruit ripening. The concentrations of SSC, total sugars, glucose and fructose in the ripe fruit were significantly reduced in response to NO treatments. In conclusion, the postharvest fumigation of NO $\left(20 \mu \mathrm{L} . \mathrm{L}^{-1}\right)$ suppressed climacteric ethylene production, respiration rate, retarded colour development, softening consequently delayed mango fruit ripening.
\end{abstract}

\section{INTRODUCTION}

Mango is a climacteric fruit. It ripens quickly and is highly perishable. Short storage life limits its export to distant markets. Postharvest exogenous application of nitric oxide (NO) has been reported to delay ripening of climacteric fruits such as banana, tomato and plum (Cheng et al., 2009; Eum et al., 2009; Singh et al., 2009). No research work has been reported on the role of NO fumigation in modulating mango fruit ripening. These observations prompted to investigate the effects of different concentrations of NO fumigation on mango fruit ripening including quality.

\section{MATERIALS AND METHODS}

\section{Plant material}

Hard mature green mango fruit (Mangifera indica L. cv. 'Kensington Pride') were obtained from Carnarvon (latitude $24^{\circ} 52^{\prime} \mathrm{S}$; longitude $113^{\circ} 38^{\prime} \mathrm{E}$ ), Western Australia. Hard mature fruit were characterized by green skin and light cream pulp colour, firmness $(139 \pm 6.08 \mathrm{~N})$, ethylene production $\left(0.06 \pm 0.01 \mathrm{nmol} \mathrm{C}_{2} \mathrm{H}_{4} \cdot \mathrm{kg}^{-1} \cdot \mathrm{h}^{-1}\right)$ and respiration rate $\left(1.64 \pm 0.04 \mathrm{mmol} \mathrm{CO}_{2} \cdot \mathrm{kg}^{-1} \cdot \mathrm{h}^{-1}\right)$. Fruit of uniform size and maturity, free from visual blemishes and diseases were selected and placed in a soft board tray before their transportation to the laboratory and used for the experiment. 


\section{NO fumigation treatments}

Fruit were fumigated with different concentration $\left(0,5,10,20\right.$ and $40 \mu{\left.\mathrm{L} . \mathrm{L}^{-1}\right)}^{-1}$ of $\mathrm{NO}$ for $2 \mathrm{~h}$ in a seal plastic container $(67 \mathrm{~L})$. Different concentrations of NO were obtained from a cylinder containing $4810 \pm 100 \mu \mathrm{L} . \mathrm{L}^{-1} \mathrm{NO}$ in Nitrogen (BOC Gases Ltd., Sydney, NSW, Australia). Following fumigation, the fruit were allowed to ripen at ambient temperature $\left(21 \pm 1^{\circ} \mathrm{C}\right)$. Control fruit were placed in the plastic container for the same duration of incubation without any NO treatment.

The experimental layout was completely randomized with two factors including NO-fumigation and ripening period. Each treatment was replicated 3-time and 10 fruit constituted single replication.

\section{Observations recorded on fruit ripening and quality during ripening at ambient temperature $\left(21 \pm 1^{\circ} \mathrm{C}\right)$}

Ethylene production, respiration rate, fruit firmness and skin colour were determined daily during fruit ripening. Fruit quality such as soluble solids concentrations (SSC), titratable acidity (TA), SSC:TA ratio and sugars concentration were also determined at eating soft ripe stage.

\section{Ethylene production and respiration rate}

Ethylene and respiration rate (carbon dioxide production) from mango fruit during ripening was determined according to the method described by Singh et al. (2009). Ethylene was estimated using a gas chromatograph (6890N Network GC system; Agilent Technology, Palo Alto, CA, USA) fitted with a $2 \mathrm{~m}$ long stainless steel column (PorapaqQ, $3.18 \mathrm{~mm}, 80 / 100$ mesh size; Sepelco, Bellefonte, PA, USA) and a flame ionization detector (FID). The ethylene production rate was calculated and expressed as nmol $\mathrm{C}_{2} \mathrm{H}_{4} \cdot \mathrm{kg}^{-1} \cdot \mathrm{h}^{-1}$.

The concentrations of $\mathrm{CO}_{2}$ were determined using an infrared gas analyzer [Servomex Gas Analyzer, Analyzer series 1450 Food Package Analyzer, Servomex (U.K.) Ltd., East Sussex, U.K.]. Respiration rate was expressed as mmol $\mathrm{CO}_{2} \cdot \mathrm{kg}^{-1} \cdot \mathrm{h}^{-1}$.

\section{Skin colour}

The colour of individual fruit was assessed by visual assessment. The visual colour of fruit skin was recorded daily during ripening period by following a rating scale of 1 to $5(1=100 \%$ green, $2=75 \%$ green, $3=50$ green/yellow, $4=75 \%$ yellow, and $5=$ $100 \%$ yellow) as described by Dang et al. (2008).

The fruit skin colour parameters including, $L^{*}, a^{*}, b^{*}$, were also recorded using a ColorFlex $45^{\circ} 0^{\circ}$ spectrophotometer (HunterLab ColorFlex, Hunter Associates Inc., Reston, VA), chroma $\left(C^{*}\right)$ and hue angle $\left(h^{\circ}\right)$ were calculated as described earlier by Dang et al., (2008). Four readings were taken from opposite positions of each fruit.

\section{Fruit softness and rheological properties of pulp}

Subjective softness of individual fruit was assessed daily using a rating scale of 1 to $5(1=$ hard, $2=$ sprung, $3=$ slightly soft, $4=$ eating soft, and $5=$ over soft $)$ as described previously by Dang et al. (2008). Rheological properties of pulp of ripe fruit including hardness, springiness, cohesiveness, chewiness, adhesiveness and stiffness were also determined using a texture analyser (TA Plus, AMETEK Lloyd Instruments Ltd., Hampshire, UK) interfaced to a personal computer with Nexygen ${ }^{\circledR}$ software. A 7/16 inch Magness-Taylor probe, with a $500 \mathrm{~N}$ load cell on, punctured to the $5 \mathrm{~cm}$ x $2 \mathrm{~cm}$ x $2 \mathrm{~cm}$ 
(length, breadth and height) pulp at a crosshead speed, trigger and compression of 2 $\mathrm{mm} . \mathrm{s}^{-1}, 0.5 \mathrm{~N}$ and $25 \%$, respectively.

\section{SSC, TA and SSC:TA ratio}

SSC and TA were determined from freshly extracted juice of ripe fruit using fruit juicer (Model JE8500, Sunbeam Corporation Ltd., China). SSC was determined using an infrared digital refractometer (Atago-Palette PR 101, Atago Co. Ltd., Itabashi-Ku, Tokyo, Japan) and expressed in percentage (\%). TA was determined by titrating fruit juice against $0.1 \mathrm{~N} \mathrm{NaOH}$ and expressed as percentage of citric acid. SSC:TA ratio was calculated by dividing the percentage of SSC with TA.

\section{Total and individual sugars}

For extraction of soluble sugars one gram of pulp was homogenized with $25 \mathrm{~mL}$ of Milli Q water. Following centrifugation at $10,000 \mathrm{rpm}$ for $15 \mathrm{~min}$ at $15^{\circ} \mathrm{C}$, the supernatant was diluted with Milli Q water to $50 \mathrm{~mL}$. It was filtered through $0.2 \mu \mathrm{m}$ nylon syringe filter [Alltech Associates (Australia) Ltd., NSW, Australia] and loaded into $1 \mathrm{~mL}$ glass vial. Individual sugars was determined according to the method described by Singh et al. (2009) except the flow rate was kept at $0.5 \mathrm{~mL} \cdot \mathrm{min}^{-1}$. The chromatographic peak of individual compound was identified by comparing retention time and spiking with standard compounds. The data were gleaned and processed with Breeze 3.30 software (Waters, Milford, MA, USA). The concentration of sucrose, glucose and fructose were expressed as g. $100 \mathrm{~g}^{-1}$ fresh weight (FW) basis.

\section{Statistical analysis}

The experimental data were subjected to analysis of variance (ANOVA) using SAS release 9.1 (SAS Institute Inc., Cary, NC, USA). The effects of various treatments and ripening period on fruit quality at ripe stage were assessed using two- and one-way ANOVA, respectively. Fisher's least significant differences (LSD) were calculated following a significant $(P \leq 0.05) F$-test. All the assumptions of ANOVA were checked to ensure validity of statistical analysis.

\section{RESULTS AND DISCUSSIONS}

\section{Ethylene production and respiration rate}

NO-fumigation significantly $(P \leq 0.001)$ suppressed climacteric ethylene peak during fruit ripening at ambient temperature (Fig. 1A). Climacteric ethylene peak was suppressed by 1.63-, 3.79-, 4.82- and 3.12-fold with 5, 10, 20 and $40 \mu{\mathrm{L} . \mathrm{L}^{-1} \mathrm{NO}}$ treatments respectively during fruit ripening, as compared to the control. All NOfumigation treatments $\left(5,10,20\right.$ and $\left.40 \mu \mathrm{L} . \mathrm{L}^{-1}\right)$ also significantly $(P \leq 0.001)$ suppressed climacteric respiration peak 1.24-, 1.26-, 1.33- and 1.46-fold respectively as compared to non-fumigated fruit (Fig. 1B). The reduction in ethylene production during fruit ripening in NO-fumigated fruit possibly may be due to reduction in activities of enzymes involved in ethylene biosynthesis such as 1-aminocyclopropane-1-carboxylic acid synthase (ACS) and 1-aminocyclopropane-1-carboxylic acid oxidase (ACO). NO has been reported to bind with ACO and 1-aminocyclopropane-1-carboxylic acid (ACC) to form a stable ternary complex (Tierney et al., 2005). It may also be argued that possibly NO may have reduced the activity of ACO and down regulated the expression MA-ACO1 gene, with higher ACS activity and ACC content accumulation as reported in banana (Cheng et al., 
2009). It is surmised that either one of these proposed or any other mechanism of action of NO in reducing ethylene production may be operating in 'Kensington Pride' mango fruit. The exact mode of action of NO in suppressing ethylene production during fruit ripening in mango fruit warrants to be investigated. Suppression of respiration during ripening in NO-fumigated fruit has also been reported earlier in plums (Singh et al., 2009), peaches (Grima-Calvo et al., 2008; Grima-Calvo et al., 2005) and strawberry (Zhu and Zhou, 2007).

\section{Fruit softness and rheological properties of the pulp}

NO fumigated fruit $\left(10,20\right.$, and $\left.40 \mu \mathrm{L} . \mathrm{L}^{-1}\right)$ significantly $(P \leq 0.001)$ reduced fruit softening $(7.37,22.11$ and $22.11 \%$ respectively) on $6 \mathrm{~d}$ of fruit ripening as compared to control (Fig. 1C). However, these NO treatments took 7, 8 and 8 days to attain softness of fully ripe fruit, respectively.

The cohesiveness, springiness and chewiness of pulp of the ripe fruit were significantly $(P \leq 0.001)$ higher $(2.07-, 1.68$ - and 3.39 -fold, respectively) in NO fumigated $\left(40 \mu \mathrm{L} . \mathrm{L}^{-1}\right)$ fruit than control (Table 1). However, non-significant impact was observed on hardness, adhesiveness and stiffness of the pulp of ripe fruit. The reduction in fruit softening and maintenance of pulp texture in NO-treated fruit may be ascribed to the reduced ethylene production during fruit ripening. Earlier, ethylene has been reported to be directly involved in promoting the activities of fruit softening enzymes, such as polygalacturonase (Lazan et al., 1986), galactosidases (Ali et al., 1995), pectin esterase and $\beta$-1,4-glucanase (Ali et al., 2004) in mango fruit. Similarly, the NO fumigation (5 or $10 \mu \mathrm{L} . \mathrm{L}^{-1}$ ) has been reported to delay fruit softening during storage and ripening period in plums, pears and peaches (Singh et al., 2009; Sozzi et al., 2003; Zhu and Zhou, 2006), but a higher concentration $\left(15 \mu \mathrm{L} . \mathrm{L}^{-1}\right)$ in peaches enhanced fruit softening. In our experiment, NO concentrations ( 20 and $\left.40 \mu \mathrm{L} . \mathrm{L}^{-1}\right)$ reduced fruit softening in mango during ripening for $8 \mathrm{~d}$, thereby delaying eating fruit soft stage up to 2 days than control fruit. The effects of $\mathrm{NO}$ on the activities of fruit softening enzymes during mango fruit ripening is yet to be investigated.

\section{Skin color}

All NO-fumigation treatments significantly $(P \leq 0.05)$ delayed fruit colour development, also reflected in chromaticity $a^{*}, b^{*}, C^{*}$ values during fruit ripening at $21 \pm 1^{\circ} \mathrm{C}$ (Fig. 2A, C, D and E) depending upon the concentration of NO applied. NOfumigation treatment $\left(40 \mu \mathrm{L}^{-\mathrm{L}^{-1}}\right)$ reduced chromaticity $L^{*}$ values during fruit ripening period day 3-8 (Fig. 2B). The decline in hue angle $\left(h^{o}\right)$ observed during fruit ripening and was slower in NO-fumigated fruit as compared to control fruit (Fig. 2F) These results reflected to the greener color of the skin than control and indicate that NO may have delayed the degradation of chlorophyll in fruit skin. Similarly in plum, the decrease in hue angle values of fruit fumigated with $20 \mu \mathrm{L}^{-\mathrm{L}^{-1}} \mathrm{NO}$ was higher than those fumigated with $10 \mu \mathrm{L} . \mathrm{L}^{-1} \mathrm{NO}$ following 5,6 , and 7 weeks storage and $5 \mathrm{~d}$ ripening at $21 \pm 1^{\circ} \mathrm{C}$ (Singh et al., 2009).

\section{Individual sugars, SSC, TA and SSC:TA ratio}

NO-fumigation treatments decreased the concentration of total sugars, sucrose, fructose, glucose and SSC in fully ripe fruit (Table 1). TA and SSC:TA ratio in ripe fruit did not show any consistent trends to the different concentrations of NO applied. Previously, a delay in the increase of SSC in peaches and kiwifruit fumigated with 5 or 10 
$\mu \mathrm{L} . \mathrm{L}^{-1} \mathrm{NO}$ and 0.5 or $1 \mu \mathrm{mol} . \mathrm{L}^{-1} \mathrm{NO}$, respectively, during ripening and storage has been reported by Zhu et al. (2006; 2008). Our data show that NO-fumigation significantly reduced SSC, concentrations of total and individual sugars such as fructose and glucose during fruit ripening. It appears that the NO-fumigation influences sugar metabolism of mango fruit during ripening and warrants further investigations.

\section{CONCLUSIONS}

NO-fumigation suppresses of climacteric ethylene production, respiration rate, which retards colour development and fruit softening as well as reduced the concentrations of sugars in 'Kensington Pride' mango fruit consequently delayed ripening.

\section{ACKNOWLEDGEMENTS}

Zaharah S.S. acknowledges the Ministry of Higher Education (Malaysia) and Universiti Putra Malaysia for financial support during her $\mathrm{PhD}$ studies. We acknowledge Ms. Susan Petersen and Mr. Ismail Iberahim for technical support.

\section{Literature Cited}

Ali, Z., Chin, L.H. and Lazan, H. 2004. A comparative study on wall degrading enzymes, pectin modifications and softening during ripening of selected tropical fruits. Plant Sci. 167: 317-327.

Ali, Z.M., Armugam, S. and Lazan, H. 1995. $\beta$-Galactosidase and its significance in ripening mango fruit. Phytochemistry. 38: 1109-1114.

Cheng, G., Yang, E., Lu, W., Jia, Y., Jiang, Y. and Duan, X. 2009. Effect of nitric oxide on ethylene synthesis and softening of banana fruit slice during ripening. J. Agri. Food Chem. 57: 5799-5804.

Dang, K.T.H., Singh, Z. and Swinny, E.E. 2008. Edible coatings influence fruit ripening, quality, and aroma biosynthesis in mango fruit. J. Agri. Food Chem. 56: 1361-1370.

Eum, H.L., Kim, H.B., Choi, S.B. and Lee, S.K. 2009. Regulation of ethylene biosynthesis by nitric oxide in tomato (Solanum lycopersicum L.) fruit harvested at different ripening stages. Eur. Food Res. Technol. 228: 331-338.

Grima-Calvo, D., Lara, I. and Vendrell, M. 2008. Application of different treatments (CA, MA, $\mathrm{N}_{2} \mathrm{O}$ and 1-MCP) to improve quality of two peach varieties. Acta Hort. 804: 129134.

Grima-Calvo, D., Peña, A.R. and Vendrell, M. 2005. Effect of different gas treatments (1$\mathrm{MCP}$ and $\mathrm{N}_{2} \mathrm{O}$ ) and MA on ethylene biosynthesis, ripening and quality of peaches. Acta Hort. 682: 973-978.

Lazan, H., Ali, Z., Lee, K., Voon, J. and Chaplin, G. 1986. The potential role of polygalacturonase in pectin degradation and softening of mango fruit. ASEAN Food J. 2: 93-95.

Singh, S.P., Singh, Z. and Swinny, E.E. 2009. Postharvest nitric oxide fumigation delays fruit ripening and alleviates chilling injury during cold storage of Japanese plums (Prunus salicina Lindell). Post. Biol. Technol. 53: 101-108.

Sozzi, G.O., Trinchero, G.D. and Fraschina, A.A. 2003. Delayed ripening of 'Bartlett' pears treated with nitric oxide. J. Hort. Sci. Biol. 78: 899-903.

Tierney, D.L., Rocklin, A.M., Lipscomb, J.D., Que Jr, L. and Hoffman, B.M. 2005. ENDOR studies of the ligation and structure of the non-heme iron site in ACC oxidase. J. Am. Chem. Soc. 127: 7005-7013. 
Zhu, S., Liu, M.C. and Zhou, J. 2006. Inhibition by nitric oxide of ethylene biosynthesis and lipoxygenase activity in peach fruit during storage. Post. Biol. Tech. 42: 41-48.

Zhu, S., Sun, L., Liu, M. and Zhou, J. 2008. Effect of nitric oxide on reactive oxygen species and antioxidant enzymes in kiwifruit during storage. J. Sci. Food Agri. 88: 2324-2331.

Zhu, S.H. and Zhou, J. 2006. Effects of nitric oxide on fatty acid composition in peach fruits during storage. J. Agri. Food Chem. 54: 9447-9452.

Zhu, S.H. and Zhou, J. 2007. Effect of nitric oxide on ethylene production in strawberry fruit during storage. Food Chem. 100: 1517-1522.

\section{$\underline{\text { Table }}$}

Table 1: Rheological properties of pulp, SSC, TA, SSC:TA ratio and concentrations of sugars ripe fruit influenced by different concentrations of NO-fumigation.

\begin{tabular}{|c|c|c|c|c|c|c|}
\hline \multirow[t]{2}{*}{ Fruit quality parameters } & \multicolumn{5}{|c|}{$\mathrm{NO}\left(\mu \mathrm{L} . \mathrm{L}^{-1}\right)$} & \multirow{2}{*}{$\begin{array}{l}\text { LSD } \\
(P \leq 0.05)\end{array}$} \\
\hline & 0 & 5 & 10 & 20 & 40 & \\
\hline Hardness (N) & 8.5 & 8.4 & 8.7 & 9.1 & 8.9 & NS \\
\hline Cohesiveness & $0.05^{\mathrm{b}}$ & $0.05^{\mathrm{b}}$ & $0.05^{\mathrm{b}}$ & $0.05^{\mathrm{b}}$ & $0.09^{\mathrm{a}}$ & $0.01^{* * *}$ \\
\hline Springiness (mm) & $1.65^{\mathrm{c}}$ & $1.7^{\mathrm{bc}}$ & $1.8^{\mathrm{bc}}$ & $1.9^{\mathrm{b}}$ & $2.8^{\mathrm{a}}$ & $0.17^{* * *}$ \\
\hline Chewiness (Nmm) & $0.7^{\mathrm{b}}$ & $0.7^{\mathrm{b}}$ & $0.8^{\mathrm{b}}$ & $1.0^{\mathrm{b}}$ & $2.3^{\mathrm{a}}$ & $0.35^{* * *}$ \\
\hline Adhesiveness (Nm) & 0.3 & 0.3 & 0.4 & 0.3 & 0.5 & NS \\
\hline Stiffness $(\mathrm{kgf} / \mathrm{mm})$ & 0.3 & 0.3 & 0.3 & 0.4 & 0.3 & NS \\
\hline Total sugar (g.100 g $\left.{ }^{-1} \mathrm{FW}\right)$ & $13.6^{\mathrm{a}}$ & $12.2^{\mathrm{ab}}$ & $9.9^{\mathrm{b}}$ & $9.8^{\mathrm{b}}$ & $9.6^{\mathrm{b}}$ & $3.09^{*}$ \\
\hline Sucrose $\left(\mathrm{g} .100 \mathrm{~g}^{-1} \mathrm{FW}\right)$ & 9.2 & 8.7 & 6.7 & 6.9 & 6.7 & NS \\
\hline Fructose (g. $\left.100 \mathrm{~g}^{-1} \mathrm{FW}\right)$ & $4.0^{\mathrm{a}}$ & $3.1^{\mathrm{b}}$ & $2.8^{\mathrm{bc}}$ & $2.5^{\mathrm{c}}$ & $2.6^{\mathrm{bc}}$ & $0.55^{* * * *}$ \\
\hline Glucose (g.100 g $\left.\mathrm{g}^{-1} \mathrm{FW}\right)$ & $0.4^{\mathrm{a}}$ & $0.4^{\mathrm{abc}}$ & $0.4^{\mathrm{ab}}$ & $0.3^{\mathrm{bc}}$ & $0.3^{\mathrm{c}}$ & $0.10^{*}$ \\
\hline $\operatorname{SSC}(\%)$ & $15.2^{\mathrm{a}}$ & $15.0^{\mathrm{a}}$ & $14.7^{\mathrm{ab}}$ & $13.6^{\mathrm{c}}$ & $13.9^{\mathrm{bc}}$ & $0.86^{* * *}$ \\
\hline $\mathrm{TA}(\%)$ & $0.4^{\mathrm{ab}}$ & $0.4^{\mathrm{ab}}$ & $0.3^{\mathrm{b}}$ & $0.4^{\mathrm{a}}$ & $0.3^{\mathrm{b}}$ & $0.08^{*}$ \\
\hline SSC:TA ratio & $42.5^{\mathrm{ab}}$ & $40.2^{\mathrm{ab}}$ & $50.8^{\mathrm{a}}$ & $31.1^{\mathrm{b}}$ & $44.0^{\mathrm{a}}$ & $11.64^{*}$ \\
\hline
\end{tabular}

Means followed by the same letters within a row are not significantly different at $P \leq 0.05$ by the Least Significant Difference (LSD) with $n=24$ (8 fruit $\times 3$ replication) for hardness, cohesiveness, springiness, chewiness, adhesiveness and stiffness and $\mathrm{n}=3$ replications for total sugar, sucrose, fructose, glucose, SSC, TA and SSC:TA ratio. *, **, significantly different at $P \leq 0.05,0.01,0.001$ respectively, and NS $=$ not significant.

\section{Figure captions}

Fig. 1: Effects of different concentrations of NO-fumigation and ripening period on (A) ethylene, (B) respiration rate and (C) fruit softness at ambient temperature $\left(21 \pm 1^{\circ} \mathrm{C}\right)$. Vertical bars represent S.E. of mean. Some error bars are not visible due to the lower value of S.E against the $y$-axis scale.

Fig. 2: Effects of different concentrations of NO-fumigation and ripening period on (A) visual fruit colour, (B) $L^{*},(\mathrm{C}) a^{*},(\mathrm{D}) b^{*}$, (E) $C^{*}$ and (F) $h^{\circ}$ during ripening at $21 \pm 1^{\circ} \mathrm{C}$. Vertical bars represent S.E. of mean. Some error bars are not visible due to the lower value of S.E against the $y$-axis scale. 
Fig 1 (Zaharah and Singh)

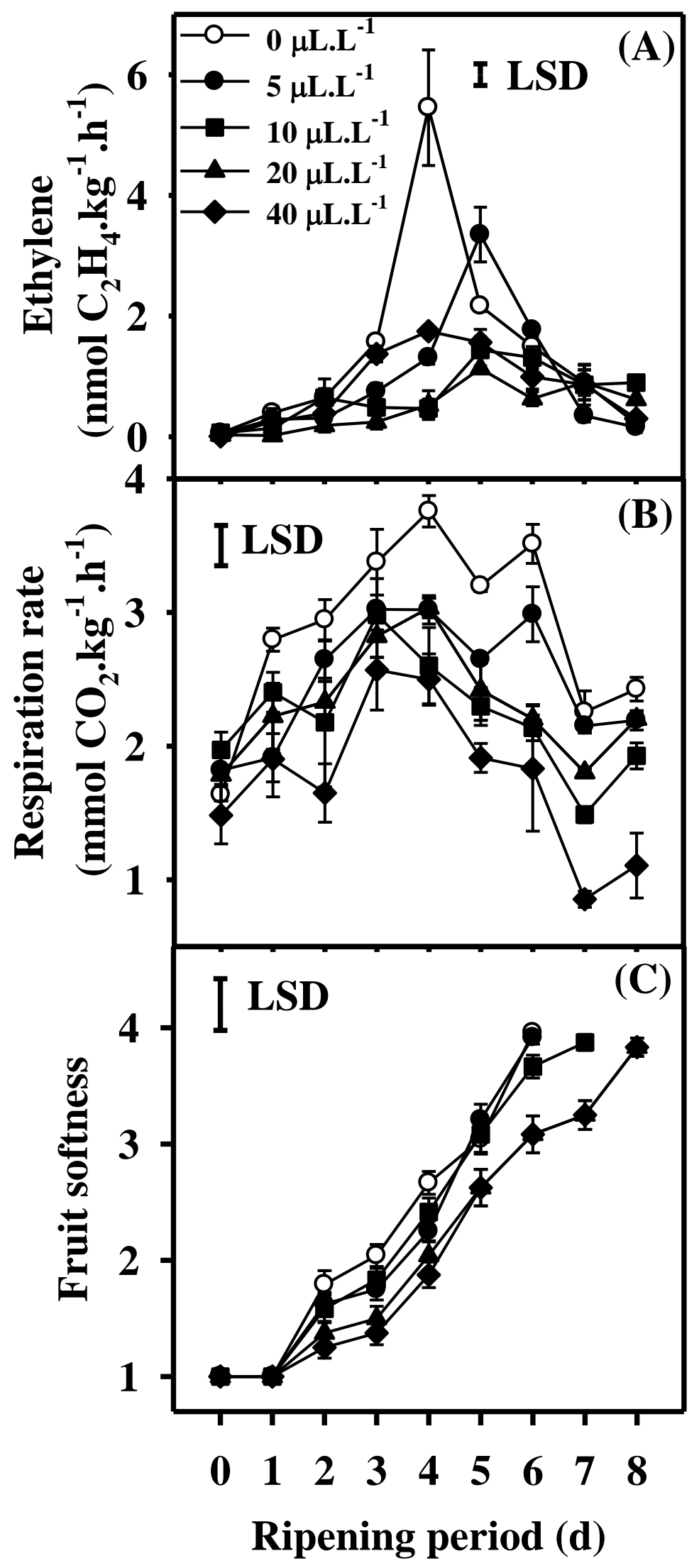


Fig 2 (Zaharah and Singh)

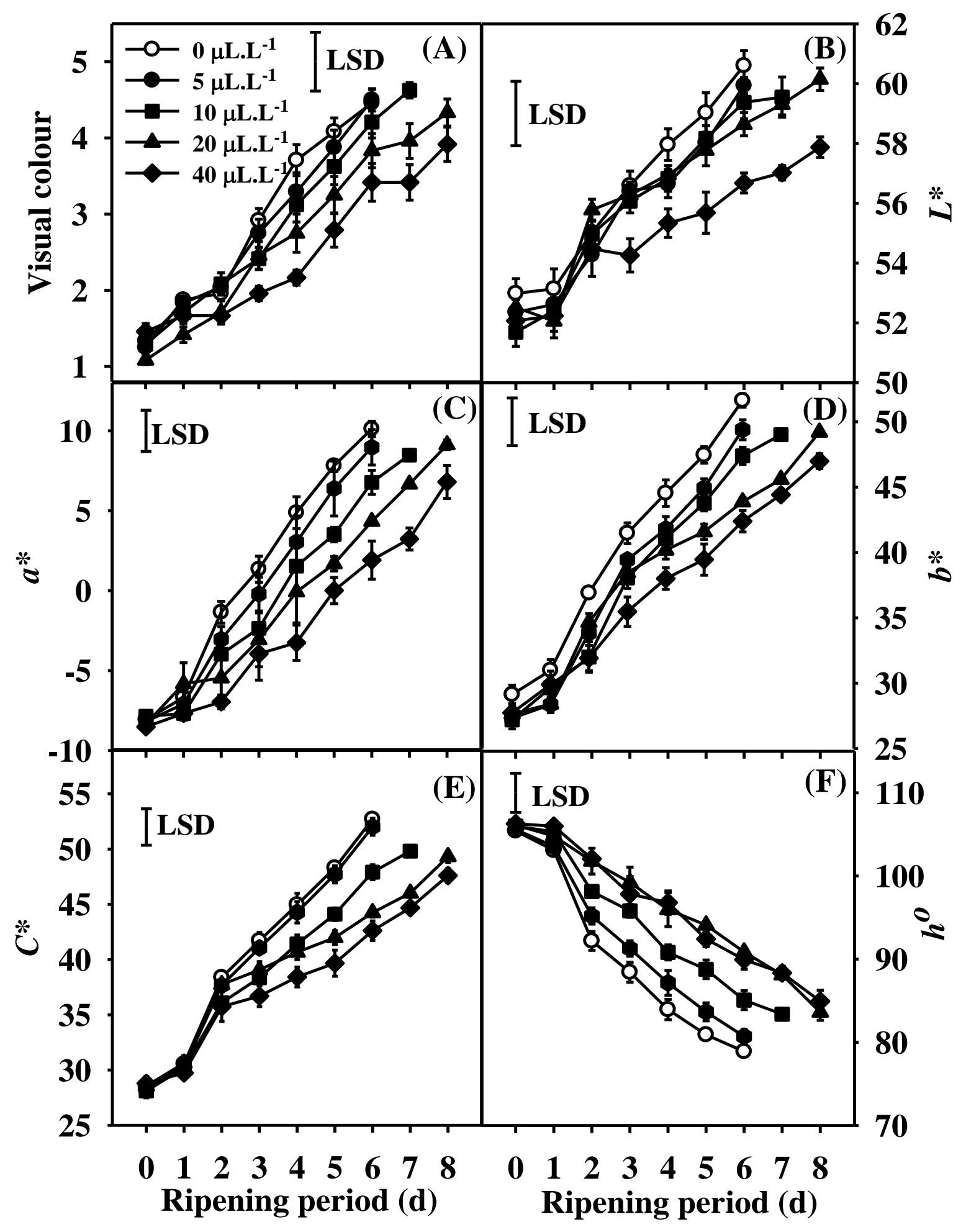

